\title{
Arquivos de Neuro-Psiquiatria in the Brazilian Academy of Neurology: natural evolution
}

\author{
Arquivos de Neuro-Psiquiatria na Academia Brasileira de Neurologia: uma evolução natural \\ Luís dos Ramos Machado, José Antonio Livramento
}

rquivos de Neuro-Psiquiatria was published for the first time in June 1943, 73 years ago. All of its editors can be proud of the fact that since its first issue, Arquivos has maintained absolute regularity of publication.

Although the journal's profile was delineated by Oswaldo Lange, Adherbal Tolosa and Paulino Longo in the midst of the Second World War, it fell to Lange to take on the hard task of bringing the journal to life and ensuring its survival at a time of enormous difficulties.

In addition to his recognized talent and Prussian discipline, Lange could count on unconditional support from his immediate family, from the outset, especially from his daughter Marília Lange Spina França. Later on, this nucleus expanded to include Antonio Spina-França Netto and subsequently his daughter Adriana Spina França Machado. Years later, José Antonio Livramento, Luís dos Ramos Machado and Silvia Regina Mielli successively entered the group of collaborators. The editorial and administrative team of Arquivos de Neuro-Psiquiatria remained limited to this group of dedicated volunteers until Marília passed away in 2009, when the journal had to become structured in a more professional manner. This team took on the task of selecting articles, providing the entire editorial process through the post (there was no SciELO and no internet), typing up the manuscripts corrected by the editor, sometimes repeatedly, correcting the proofs from the printers, packaging the journals and putting them in the post. The work of producing the journal was carried out in the family's own home until 2010, when Spina França acquired the present main office with funds that had been hoarded over many years by the Associação Arquivos de Neuro-Psiquiatria Dr. Oswaldo Lange. The vocation and family characteristics were therefore not a matter of choice, but the only way of keeping the journal alive with the meager resources available.

The major changes that took place at the end of the last century and the beginning of this, with the adoption of peer review, the entry into SciELO and the open-access system, use of online submission software, publication of texts exclusively in English and the service agreement with a specialized graphic production company. One event of great satisfaction for the journal's current board was the insertion of all issues of the journal, all the way back to 1943, in the SciELO collection.

On the other hand, the Brazilian Academy of Neurology (Academia Brasileira de Neurologia, ABN) was created in 1962, thus coming to life many years after Arquivos. Like most medical specialty societies, for a long time, the $\mathrm{ABN}$ faced difficulties in becoming established as the representative society for Brazilian neurology. Soon after the ABN had been created, Lange proposed that Arquivos should be its official journal, given that the journal was already established, had a respected name and was indexed, and that the ABN would find it difficult to bring together the conditions for taking on the production of a journal with these characteristics. Fortunately, especially over the past decade, this situation has changed radically and the $\mathrm{ABN}$ has grown greatly and has come to have more resources and a highly qualified administrative structure.

Over the last few years, the present editors of Arquivos have promoted broad opening up of the journal, with the aim of emphasizing its national nature and its vocation as the journal that represents Brazilian neurology. More than 80 associate editors and area supervisors in all 
regions of Brazil and some of them abroad were selected and invited to participate, and have been fully operational for the last three years. In a committee that the directorate of the ABN also form part of, Carlos Alberto Mantovani Guerreiro and Hélio Guizoni Teive were chosen for the position of new editors-in-chief of Arquivos, to take power at the end of 2017.

After intensive and extensive negotiations with the current directorate of the $\mathrm{ABN}$, and thanks especially to the participation of its president, Rubens José Gagliardi, incorporation of Arquivos by ABN was established. This includes the journal's financial assets and ownership of the its main office.
This incorporation, without any onus for the ABN, was approved at a general meeting of the ABN in July 2015 and is now being implemented.

In this manner, Arquivos will start to be administered by the ABN but will maintain absolute editorial independence. This was the essential condition for the incorporation process and we hope that it will be respected religiously by future directorates of the ABN.

Thus, in a completely natural manner, the journal has legally and really become the official journal of the $\mathrm{ABN}$, while keeping its identity and modus operandi intact. 